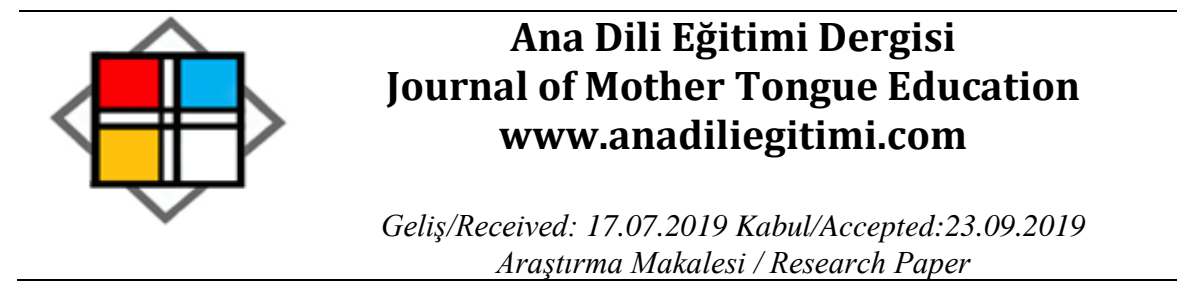

\title{
6. Sınıf Türkçe Ders Kitabı’nda Yer Alan Temalardaki Metinlerin Kök Değerlerle İlişkisi ${ }^{*}$
}

\author{
Hasan Hüseyin MUTLU** \\ Sinem DiNÇ***
}

\begin{abstract}
Öz
Günümüzün değişen şartlarına rağmen toplumda derin iz bırakan ve kültür aktarımını sağlayıp gelecek kuşaklara yön veren değerler, bireylerin sahip çıkması gereken en temel manevi unsurların başında gelmektedir. Bireylerin değerleri kazanması sürecinin önemli bir kısmını okul yaşantısı oluşturmaktadır. Milli kültürümüzün temel yapı taşlarından olan kök değerlerin büyük bir çoğunluğu programın uygulayıcısı olan ders kitapları ve metinler aracılığıyla kazanılmaktadır. Bireylerin temalarda yer alan bu değerleri davranışlarına yansıtabilmeleri için öncelikle değerlerin farkına varıp içselleştirmeleri gerekmektedir. Böylece birey davranışlarını yönlendirerek kişiliğini sosyal, duygusal, bilişsel ve ahlaki yönden geliştirmektedir. Bu çalışmanın amacı Millî Eğitim Bakanlığımızın hazırladığı 6 . Sınıf Türkçe Ders Kitabı'nda yer alan temalardaki metinlerin kök değerlerini tespit etmek ve bu değerlerin metinlerle ilişkisini belirlemektir. Araştırma nitel araştırma metodolojisine uygun olarak hazırlanmıştır. Araştırmanın veri analizinde içerik analizi yöntemi kullanılmıştır. Araştırmanın materyalini, MEB Ortaokul ve İmam-Hatip Ortaokulu 6. Sınıf Ortaokul Türkçe Ders Kitabı'ndaki 8 tema içerisinden 24 okuma metni ve 8 dinleme metni olmak üzere toplam 32 metin (belge/doküman) oluşturmaktadır. Serbest okuma metinleri, kapsam dışı tutulmuştur. Araştırma sonucunda çocukların temalarda yer alan metinlerdeki değerleri kazanmasında edebi eserlerin rolüne değinilmiş ve bu bağlamda Türkçe ders kitaplarında yer alan metinlerin seçimine gösterilmesi gereken özenin önemi vurgulanmıştır.
\end{abstract}

Anahtar Kelimeler: Türkçe eğitimi, ders kitabı, değerler, tema

\section{The Relationship between the Texts in the $6^{\text {th }}$ Grade Turkish Course Book and Core} Values

\begin{abstract}
Despite the ever changing circumstances of today, values which leave their marks on society and guide future generations through the transfer of culture, stand out among the most fundamental moral elements that the individuals must hold. Experiences in school play a significant role in individuals' acquisition of their values. The majority of the core values that are among the building blocks of our national culture are acquired through textbooks and texts which function as the implementing tools of the curriculum. In order for individuals to display those values in their behaviors, they primarily need to be conscious of them and internalize them. Through this process, individuals shape their behaviors and develop their personality socially, emotionally, cognitively and morally. The purpose of this study is to determine both the core values included in the texts of the $6^{\text {th }}$ grade Turkish course books prepared by the Ministry of Education (MEB) and the
\end{abstract}

\footnotetext{
* Bu araştırma XII. Uluslararası Eğitim Araştırmaları Kongresi'nde (25-28 Nisan 2019, Rize) sözlü bildiri olarak sunulmuştur.

** Dr. Öğr. Üyesi Ordu Üniversitesi, Eğitim Fakültesi, Ordu, hasanhuseyinmutlu@hotmail.com, ORCID: 00000002-9082-709X

*** Ordu Üniversitesi Sosyal Bilimleri Enstitüsü, Ordu, sinemdinc1552@gmail.com, ORCID:0000-0003- 0694$067 X$
} 
relationship between the texts and the values. The study is qualitative by design. Content analysis was used as the method of data analysis. The texts used for analysis in this study are a total of 32 texts (written/audio) - 24 reading texts and 8 listening texts in the eight themes in the $6^{\text {th }}$ grade secondary school Turkish course book taught at the MEB secondary schools and Imam-Hatip secondary schools. Extensive reading texts were not included. The results pointed out the role literary pieces played a role in children's acquisition of the values in the texts of the themes and also indicated that due attention has to be given in the selection of the texts in Turkish course books.

Keywords: Turkish education, course book, values, unit

\section{Giriş}

Uluslararası araştırmalarda "values education" ya da "character education" olarak adlandırılan değerler eğitiminin, ülkemizde yapılan araştırmalara bakıldığında, özellikle son zamanlarda daha fazla önem kazandığı görülmektedir. Literatürde değer kavramına ilişkin çeşitli tanımlamalarla karşılaşılmaktadır. Türk Dil Kurumunun sözlüğünde (2018); "bir şeyin önemini belirlemeye yarayan soyut ölçü, bir şeyin değdiği karşıllık, kıymet" ve "bir ulusun sahip olduğu sosyal, kültürel, ekonomik ve bilimsel değerlerini kapsayan maddi ve manevi ögelerin bütünü" olarak tanımlanmıştır. Öncül (2000: 281) değer kavramını; "genel olarak bir nesneye, varlığa ya da faaliyete ruhsal, ahlaksal, toplumsal açıdan ya da estetik yönden tanınan önem ya da üstünlük derecesi” olarak tanımlamaktadır. Bacanlı (2011) ise değeri insanların davranışlarına yön veren ilkeler, tercihler olarak tanımlamaktadır. Dolayısıyla değeri tutum, eğilim, ihtiyaç, davranış, duygu, inanç gibi kavramlarla ilişkilendirmek mümkündür.

İnsanı diğer canlılardan ve yapay zekâdan ayıran en önemli unsur sahip olduğu değerlerdir. Bireyin ortaya koyduğu karakter bir anlamda sahip olduğu değerlerin bütünüdür. McCullough ve Snyder (2000) psikolojik bağlamda değer ya da erdem kavramını kişinin kendisine ve topluma yararlı düşünce ve davranışlarını kapsayan psikolojik süreç olarak açıklamaktadır. Bu erdemlerin bir araya gelerek daha üst düzey bir kavram olan "karakteri" oluşturduğunu belirtmektedirler. Peterson ve Seligman (2004) ise olumlu kişilik özelliklerini değer kavramıyla açıklamakta, bu değerlerin bir araya gelerek "erdemi" ortaya çıkardığını öne sürmektedir. Dolayısıyla karakter oluşumunun ve erdemli davranışların ortaya çıkasında en önemli nokta bireyde bulunması gereken değerlerdir. İçten bir güç olarak değerler bireysel davranışları etkiler, yaşamda ikilemde kalma durumunda karar vermeyi kolaylaştıır (Kasapoğlu, 2013; Akt. Güçlü, 2015). Bu değerleri en temelde insani davranışları belirleyen ve dünyada ortak yaşamın oluşmasını ve devam etmesini sağlayan evrensel değerler ve bir topumun karakterini yansıtan, o toplumu bir arada tutan, besleyen ulusal değerler olarak sınıflamak mümkündür. Değerler okul öncesi dönemde aile ve çevre yoluyla, okul döneminde ise eğitim ve yine etkileşimde olduğu çevre yoluyla bireylere aktarılmaktadır.

Değerlerin bireye aktarılması sürecinin büyük bir kısmını okul yaşantısı oluşturmaktadır. Birey ilk olarak ailesinden gördüğü saygı, sevgi, yardımlaşma gibi değerleri kavrayarak bunları zihnine 


\section{Sınıf Türkçe Ders Kitabı’nda Yer Alan Temalardaki Metinlerin Kök Değerlerle İlişkisi}

yerleştirmeye başlar. Ardından okul hayatında başta Türkçe dersi olmak üzere diğer derslerle beraber metinler aracılığı ve çevresi ile sosyal etkileşimi sonuncunda çeşitli değerleri öğrenir. Böylece kendini geleceğe ve hayata hazırlar (Güneş, 2015). Berkowitz (2011) değerler eğitimini ahlaki eğitim, pozitif psikoloji ve sosyal öğrenme olarak tanımlar ve bu süreci öğrenci karakterinin gelişimini destekleyen eğitim uygulamaları olarak açıklar. Berkowitz'e göre (2011) karakter, bireyi yetkin bir ahlaki ajan olarak işlev görmesi, yani dünyada "iyi" şeyler yapması için motive eden psikolojik özellikler kümesidir. Dolayısıyla Eğitimin amaçlarından belki de en önemlisi toplumun değer yargılarını özümseyen ve kendisinden sonraki nesle aktaran bireyler yetiştirmektir. Eğitim kurumlarının genel hedefleri incelendiğinde hedeflerin birçoğunun vatansever olma, temiz olma, sağlığına dikkat etme, düzenli olma, adil olma, yaratıcı olma, girişimci olma gibi birçok değer içerdiği görülmektedir. Eğitim kurumları bunlar ve benzeri değerler ile öğrencilere neyin önemli olduğunu kavratmaya çalışır ve nasıl yaşanması gerektiği konusunda öğrencilere yol gösterip rehberlik eder (Akbaş, 2008). Değerlerin çok sayıda özelliğinden söz etmek mümkündür. Bu açıdan küçük yaşlardan itibaren değer eğitimi üzerinde önemle durulmalıdır. Eğitim-öğretim sürecinde Türkçe dersi ve metinler bu amaç için onları etkileme ve farkındalık kazandırma özelliğine sahiptir. Türkçe ders kitabında yer alan temalardaki metinler öğrenciye temel dil becerilerini kazandırmada ve değerlerin gelecek nesillere devredilmesini, aşılanmasını sağlamada ilk sıra da yer almaktadır (Şen, 2008: 765).

Cumhuriyetten günümüze kadar uygulanan Türkçe öğretim programlarında değerlere vurgu yapılmış, Türkçe öğretiminin amaçları içerisinde birtakım değerlere yer verilmiştir. 1929 Orta Mektep Türkçe Öğretim Programı'nda Türkçe dersinin başlıca gayeleri başlığı altında "milli, ahlaki, içtimai gaye" olarak değerlerler bir başlık altında belirtilmiştir. Programa göre talebeye asil mefkûreler, milli, vatani, kahramanca duygular telkin etmek, seciyesini teşkile yardım etme, onu içtimai, milli hayatta daha müsmir ve daha faal bir fert olarak yetiştirmek Türkçe dersinin amaçları içerisindedir. Değerler, 193132 Sene-i tadilat ve 1938 programlarında hiç değiştirilmeden aynı şekilde yer almıştır. 1949 ve 1962 programlarında milli değerlerin yanında "metinler yoluyla hayatı ve tabiatı tanımak ve sevmek" şeklinde program genel amaçları içinde vurgulanmıştır. 1981 programının genel amaçlarında “öğrencilerin ulusal duygusunu ve ulusal coşkusunu güçlendirmek, sözlü ve yazılı Türk ve dünya kültür ürünleri yoluyla, Türk kültürünü tanıma ve kazanmalarında, Türk yurdunu ve ulusunu doğayı hayatı insanlığı sevmelerine yardımcı olmak" şeklinde değerlere atıf yapılmıştır (Temizyürek ve Balcı, 2006).

Tamamen farklı bir yaklaşım temel alınarak hazırlanan 2006 İkinci Kademe Türkçe Öğretim Programı değerler konusuna daha önceki programlara nazaran en fazla yer veren ve ayrıntılı olarak ele alan program olmuştur. Programın yaklaşım kısmında "Türkçe Dersi Öğretim Programı́yla dinlediklerini, izlediklerini ve okuduklarını anlayan; duygu, düşünce ve hayallerini anlatan; eleştirel ve yaratıcı düşünen, sorumluluk üstlenen, girişimci, çevresiyle uyumlu, olay, durum ve bilgileri kendi 
birikimlerinden hareketle araştırma, sorgulama, eleştirme ve yorumlamayı alışkanlık hâline getiren, estetik zevk kazanmış ve millî değerlere duyarlı bireyler yetiştirilmesi amaçlanmıştır" denilerek değerlere vurgu yapılmıştır (MEB, 2006).

Değerler, programın her aşamasında planlı olarak yer almıştır. Temalarda ve alt temalarda vatan ve millet, sevgisi, dostluk, yardımlaşma, bağışlama, konukseverlik, sorumluluk gibi milli manevi değerlerle birlikte estetik değerler ve siyasal değerler doğrudan yer almıştır.

Yenilenen Türkçe Öğretim Programı'nda (2018) ise değerlerin kazandırılmasının eğitim programlarının bir işlevi olduğu vurgulanmıştır. Bu programda değerler, ayrı bir program veya öğrenme alanı, ünite, konu vb. olarak görülmemiştir. Bütün eğitim sürecinin nihai gayesi ve ruhu olan değerlerimiz, öğretim programlarının her birinde ve her bir biriminde yer almıştır. Öğretim programlarında yer alan "kök değerler"; adalet, dostluk, dürüstlük, öz denetim, sabır, saygı, sevgi, sorumluluk, vatanseverlik, yardımseverlik olarak belirtilmiştir. Bu değerler, öğrenme öğretme sürecinde hem kendi başlarına hem ilişkili olduğu alt değerlerle ve hem de öteki kök değerlerle birlikte ele alınarak hayat bulacaktır (MEB, 2018).

Bu tanım ve açıklamalardan yola çıkarak programda yer alan kök değerler bireylerin davranışlarına yön vererek karar vermelerine yardımcı olan kaynakların başında yer almaktadır. Bu bağlamda dünden bugüne ulaşmış ve yarınlara aktaracağımı milli kültürün aktarıcısı olan değerler duygu, düşünce ve davranışların toplumsal bütünlüğünün ayrılmaz bir ögesini oluşturmaktadır.

Bu araştırmanın amacı 6. Sınıf Türkçe Ders Kitabı'nda yer alan metinlerin Türkçe Dersi Öğretim Programı'ndaki (2018) kök değerlerle ve bu değerlerin hangi temadaki metinlerle ilişkili olduğunu belirlemektir. Çalışmada 6. Sınıf Türkçe Ders Kitabı çalışma materyali olarak belirlenmiştir. Bireylerin davranışlarına yön verip toplumla uyumunu sağlayan değerler, özellikle Türkçe ders kitaplarında yer alan metinlerle aktarılmaktadır. Çünkü programın uygulayıcısı ders kitapları bu amaca ulaşmada en önemli somut materyallerdir. Türkçe dersi öğretim programının amaçlarından biri millî, ahlaki, manevi ve kültürel değerlerini tanıyabilen ve benimseyen fertler yetiştirerek değerlerimizin korunması ve yeni nesillere aktarıımasını sağlamaktır. Türkçe öğretim programının 2018 yılında yenilenmesi program ögelerinin, programa bağlı materyallerin incelenmesini, değerlendirilmesini gerekli kılmaktadır. Pek tabi bugüne kadar değerlerle ilgili birçok araştırma yapılmıştır. Ancak belirtildiği üzere yapılan yenilik ve güncellemeler yeni araştırma konularını da beraberinde getirmektedir. Bununla birlikte bu çalışmanın konusu olan değerlerin bireye aktarılmasındaki en önemli unsur ders kitaplarıdır. Dolayısıyla bu durum çalışmanın gerekçesini oluşturmaktadır. Bu bağlamda çalışmanın alana katkı sağlayacağı düşünülmektedir. 


\section{Yöntem}

\section{Araştırmanın Modeli}

Araştırma, nitel araştırma özelliği taşımaktadır ve temel nitel araştırma deseninde oluşturulmuştur. Temel nitel araştırma, tüm disiplin alanlarında ve pratikte uygulama alanlarında görülebilen, eğitimde kullanılabilen en yaygın nitel araştırma biçimlerindedir. Bu araştırma türünde veriler; gözlem, görüşme ya da doküman incelemesi yoluyla toplanır (Merriam, 2013).

\section{Çalışma Materyali}

Araştırmanın materyalini, MEB Ortaokul ve İmam-hatip Ortaokulu 6. Sınıf Türkçe Ders Kitabındaki 8 tema içerisinden 24 okuma metni ve 8 dinleme metni olmak üzere toplam 32 metin (belge/doküman) oluşturmaktadır. Serbest okuma metinleri kapsam dışı tutulmuştur.

\section{Veri Toplama Aracı}

Araştırmanın veri toplama aracını, Türkçe Dersi Öğretim Programı’nda (2018) yer alan kök değerlerden hareketle oluşturulmuş (adalet, dostluk, dürüstlük, sorumluluk, yardımseverlik, öz denetim, saygı, sevgi, vatanseverlik, sorumluluk) değerler listesi oluşturmaktadır.

\begin{tabular}{lc}
$\mathrm{Nu}$ & Değerler \\
\hline 1 & Adalet \\
2 & Dostluk \\
3 & Dürüstlük \\
4 & Sorumluluk \\
5 & Yardımseverlik \\
6 & Öz denetim \\
7 & Saygı \\
8 & Sevgi \\
9 & Vatanseverlik \\
10 & Sorumluluk \\
\hline
\end{tabular}

Verilerin Toplanması ve Analizi

Araştırmada verilerin toplanması doküman incelemesi yöntemiyle yapılmıştır. Doküman incelemesi, araştırılması istenen olgu veya olgular hakkında bilgi içeren materyallerin analizi anlamına gelmektedir (Yıldırım ve Şimşek, 2011). Araştırmanın verileri, içerik analizi ile ortaya çıkarılmıştır. Türkçe ders kitabında yer alan her temadaki metinler tek tek incelenmiş, her metinde vurgulanan değerler cümle cümle tespit edilmiş elde edilen bulgular çizelgeler şeklinde sunulmuş ve yorumlanmıştır. 


\section{Bulgular}

Bu bölümde, incelenen 6.sınıf Türkçe Ders Kitabı ile 2018 İlköğretim Türkçe Dersi Öğretim Programı́nda yer alan kök değerlerin ilişkisi tablolar yardımıyla verilmeye çalışımıştır. Türkçe ders kitabında yer alan "Okuma Kültürü" adlı temada yer alan metinler ve kök değerler Tablo 2'de verilmiştir.

Tablo 2. "Okuma Kültürü" Temasında Yer Alan Metinlerin Kök Değerlerle ilişkisi

\begin{tabular}{|c|c|c|c|c|c|c|c|c|c|c|c|}
\hline METIN & $\frac{\frac{\pi}{\frac{\pi}{\pi}}}{\frac{\pi}{2}}$ & 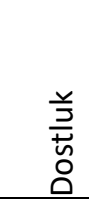 & 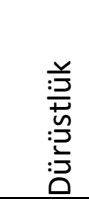 & $\begin{array}{l}\frac{E}{ \pm} \\
\stackrel{U}{U} \\
\frac{d}{0} \\
N \\
: 0\end{array}$ & $\frac{\vdots}{0}$ & 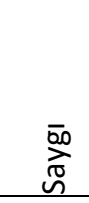 & 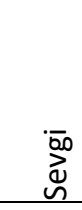 & 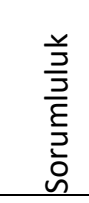 & 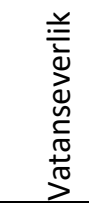 & 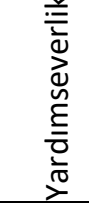 & $\begin{array}{l}\frac{\varepsilon}{\pi} \\
\frac{\pi}{0} \\
\stackrel{0}{\circ}\end{array}$ \\
\hline $\begin{array}{l}\text { Bu da Benim } \\
\text { Öyküm }\end{array}$ & - & - & - & - & 1 & - & 1 & - & - & - & 2 \\
\hline Arıyorum & - & - & - & - & - & - & - & 3 & 1 & - & 4 \\
\hline Canım Kitaplığım & - & 2 & 1 & - & 1 & - & 2 & - & - & - & 6 \\
\hline $\begin{array}{l}\text { Heykeli Dikilen } \\
\text { Eşek }\end{array}$ & - & - & 1 & - & - & - & 2 & 1 & - & 6 & 10 \\
\hline Toplam & 0 & 2 & 2 & 0 & 2 & 0 & 5 & 4 & 1 & 6 & 22 \\
\hline
\end{tabular}

Tablo 2 incelendiğinde; "Okuma Kültürü" temasında yer alan "Bu da Benim Öyküm" başlıklı metinde sabır 1, sevgi 1 olmak üzere toplam 2 kök değer tespit edildiği görülmektedir. "Arıyorum" başlıklı metinde sorumluluk 3, vatanseverlik 1 olmak üzere toplam 4 kök değer, "Canım Kitaplığım" başıklı metinde dostluk 2, sevgi 2, dürüstlük 1, sabır 1 olmak üzere toplam 6 kök değer görülmektedir. “Heykeli Dikilen Eşek" başlıklı metinde yardımseverlik 6, sevgi 2, dürüstlük 1, sorumluluk 1 olmak üzere toplam 10 kök değer, "Okuma Kültürü" adlı temada yer alan metinlerde toplam yardımseverlik kök değeri 6 , sevgi kök değeri 5 , sorumluluk 4, dostluk 2, dürüstlük 2 , sabır 2 , vatanseverlik kök değeri ise 1 kez görülmüştür. Adalet, öz denetim, saygı kök değerleri ise belirlenememiştir. Tablo 3’ te yer alan veriler doğrultusunda değerlerin dengeli bir şekilde dağılmadığı söylenebilir.

Türkçe ders kitabında yer alan "Millî Mücadele ve Atatürk" adlı temada yer alan metinler ve kök değerler Tablo 3’te gösterilmiştir.

Tablo 3. "Millî Mücadele ve Atatürk" Temasında Yer Alan Metinlerin Kök Değerlerle ilişskisi

\begin{tabular}{|c|c|c|c|c|c|c|c|c|c|c|c|}
\hline METIN & $\frac{\frac{+}{0}}{\frac{\pi}{0}}$ & $\begin{array}{l}\frac{y}{J} \\
\frac{\pi}{n} \\
\stackrel{0}{0}\end{array}$ & 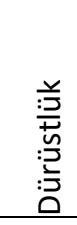 & 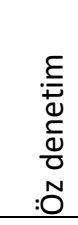 & $\frac{\vdots}{\sqrt[0]{0}}$ & 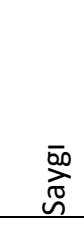 & बे & 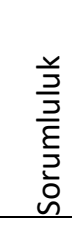 & 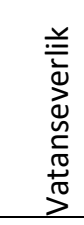 & 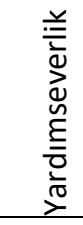 & $\frac{\frac{\varepsilon}{\sigma}}{\frac{0}{0}}$ \\
\hline $\begin{array}{l}\text { Türk Askerinin } \\
\text { Cesareti }\end{array}$ & - & - & - & - & - & - & - & - & 1 & 1 & 2 \\
\hline Yaşlı Nine & - & - & - & - & - & - & 3 & - & 3 & 1 & 7 \\
\hline
\end{tabular}




\begin{tabular}{|c|c|c|c|c|c|c|c|c|c|c|c|}
\hline 15 Temmuz & - & - & - & - & - & - & - & - & 2 & - & 2 \\
\hline 120 & - & - & 1 & - & - & - & 3 & 2 & 10 & 2 & 18 \\
\hline Toplam & 0 & 0 & 1 & 0 & 0 & 0 & 6 & 2 & 16 & 4 & 29 \\
\hline
\end{tabular}

Tablo 3'e göre "Millî Mücadele ve Atatürk" temasında yer alan "Türk Askerinin Cesareti” başlıklı metinde vatanseverlik 1, yardımseverlik 1 olmak üzere toplam 2 kök değer tespit edilmiştir. "Yaşlı Nine" başlıklı metinde sevgi 3, vatanseverlik 3, yardımseverlik 1 olmak üzere toplam 7 kök değer tespit edilmiştir. "15 Temmuz" başlıklı metinde sadece 2 vatanseverlik kök değeri tespit edilmiştir. "120" başlıklı metinde vatanseverlik 10, sevgi 3, sorumluluk 2, yardımseverlik 2, dürüstlük 1 olmak üzere toplam 18 kök değer tespit edilmiştir. "Millî Mücadele ve Atatürk" adlı temada yer alan metinlerde toplam vatanseverlik kök değeri 16, sevgi kök değeri 6, yardımseverlik 4, sorumluluk 2, dürüstlük kök değeri ise 1 kez görülmüştür. Adalet, dostluk, öz denetim, sabır, saygı kök değerleri ise belirlenememiştir.

Türkçe ders kitabında yer alan "Bilim ve Teknoloji" adlı temada yer alan metinler ve kök değerler Tablo 4'te gösterilmiştir.

Tablo 4. "Bilim ve Teknoloji" Temasında Yer Alan Metinlerin Kök Değerlerle Ilişkisi

\begin{tabular}{|c|c|c|c|c|c|c|c|c|c|c|c|}
\hline METIN & $\frac{\frac{t}{0}}{\frac{\pi}{0}}$ & 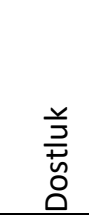 & 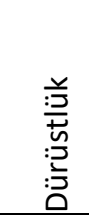 & $\begin{array}{l}\underline{E} \\
\mathcal{U} \\
\tilde{\Phi} \\
\tilde{D} \\
: 0\end{array}$ & $\frac{\overline{0}}{n}$ & $\underset{n}{\stackrel{50}{\pi}}$ & 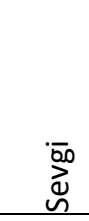 & $\begin{array}{l}\frac{\text { J }}{3} \\
\frac{3}{E} \\
\frac{5}{3} \\
0 \\
0\end{array}$ & 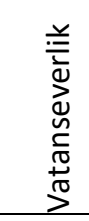 & 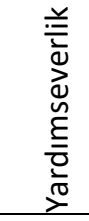 & $\begin{array}{l}\frac{\varepsilon}{\sigma} \\
\frac{\pi}{0} \\
\stackrel{0}{\circ}\end{array}$ \\
\hline $\begin{array}{l}\text { Aziz } \\
\text { Sancar }\end{array}$ & - & - & - & - & 1 & 2 & 2 & 1 & 9 & 2 & 17 \\
\hline $\begin{array}{l}\text { Insanlar } \\
\text { Zamanı } \\
\text { Eskiden } \\
\text { Nasıl } \\
\text { Ölçerdi? }\end{array}$ & - & - & - & - & - & - & - & - & - & - & 0 \\
\hline $\begin{array}{l}\text { Teknoloji } \\
\text { Bağımlılığı }\end{array}$ & - & - & - & - & - & - & - & - & - & - & 0 \\
\hline $\begin{array}{l}\text { Bak } \\
\text { Postacı } \\
\text { Geliyor } \\
\text { Selam } \\
\text { Veriyor }\end{array}$ & - & - & - & - & - & - & - & - & - & - & 0 \\
\hline Toplam & 0 & 0 & 0 & 0 & 1 & 2 & 2 & 1 & 9 & 2 & 17 \\
\hline
\end{tabular}

Tablo 4'te; "Bilim ve Teknoloji" temasında yer alan "Aziz Sancar" başlıklı metinde vatanseverlik 9, yardımseverlik 2, saygı 2, sevgi 2, sabır 1 , sorumluluk 1 olmak üzere toplam 17 kök değer tespit edilmiştir. "Insanlar Zamanı Eskiden Nası Ölçerdi?”, “Teknoloji Bağımlılı̆ı” ve "Bak Postacı Geliyor Selam Veriyor" başlıklı metinlerde ise herhangi bir kök değer belirlenememiştir. "Bilim ve Teknoloji" 
adlı temada yer alan metinlerde toplam vatanseverlik 9, saygı 2, sevgi 2, yardımseverlik 2, sabır ve sorumluluk kök değeri ise 1 kez görülmüştür. Adalet, dostluk, dürüstlük ve öz denetim kök değerleri ise bulunamamıştır.

Türkçe ders kitabında yer alan "Erdemler" adlı temada yer alan metinler ve kök değerler Tablo 5 'te gösterilmiştir.

Tablo 5. "Erdemler" Temasında Yer Alan Metinlerin Kök Değerlerle iliş̌isi

\begin{tabular}{|c|c|c|c|c|c|c|c|c|c|c|c|}
\hline METIN & $\frac{\frac{4}{0}}{\frac{\pi}{\alpha}}$ & 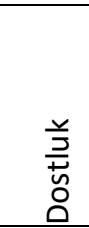 & 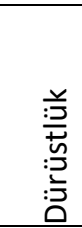 & 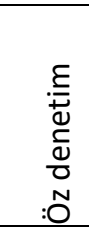 & 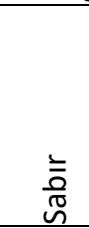 & 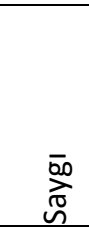 & 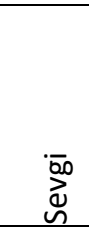 & $\begin{array}{l}\frac{y}{3} \\
\frac{3}{\bar{E}} \\
\frac{\xi}{2} \\
0 \\
0\end{array}$ & 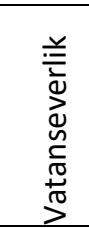 & 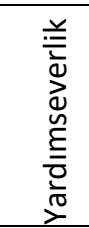 & $\begin{array}{l}\frac{\varepsilon}{\pi} \\
\frac{0}{0} \\
\text { 은 }\end{array}$ \\
\hline $\begin{array}{l}\text { Vermek } \\
\text { Çoğalmaktır }\end{array}$ & 1 & 2 & - & - & - & - & 2 & - & - & 2 & 7 \\
\hline $\begin{array}{l}\text { Sevgi Diyen } \\
\text { Çağlar Aşar }\end{array}$ & - & & - & - & - & - & 4 & - & - & - & 4 \\
\hline Gümüş Kanat & - & & - & - & - & - & 2 & - & - & 2 & 4 \\
\hline Balıkçıl & - & - & 1 & - & 1 & - & - & - & - & - & 2 \\
\hline Toplam & 1 & 2 & 1 & 0 & 1 & 0 & 8 & 0 & 0 & 4 & 17 \\
\hline
\end{tabular}

Tablo 5 incelendiğinde; "Erdemler" temasında yer alan "Vermek Çoğalmaktır" başlıklı metinde dostluk 2, sevgi 2, yardımseverlik 2, adalet 1 olmak üzere toplam 7 kök değer, "Sevgi Diyen Çağlar Aşar" başlıklı metinde sadece 4 sevgi kök değeri, "Gümüş Kanat” başlıklı metinde sevgi 2, yardımseverlik 2 olmak üzere toplam 4 kök değer, "Balıkçıl" başlık metinde dürüstlük 1, sabır 1 olmak üzere toplam 2 kök değer tespit edildiği görülmektedir. "Erdemler" adlı temada yer alan metinlerde toplam sevgi, 8 yardımseverlik 4, dostluk 2, adalet, dürüstlük ve sabır kök değerleri ise 1 kez görülmüştür. Öz denetim, saygı, sorumluluk ve vatanseverlik kök değerleri ise belirlenememiştir.

Türkçe ders kitabında yer alan "Doğa ve Evren" adlı temada yer alan metinler ve kök değerler Tablo 6'da gösterilmiştir.

Tablo 6. "Doğa ve Evren" Temasında Yer Alan Metinlerin Kök Değerlerle iliş̧kisi

\begin{tabular}{|c|c|c|c|c|c|c|c|c|c|c|c|}
\hline METIN & $\frac{\frac{\pi}{\pi}}{\frac{\pi}{2}}$ & 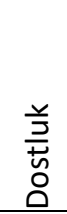 & 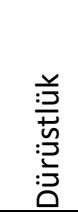 & 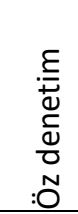 & 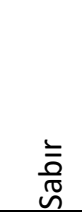 & 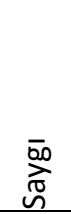 & 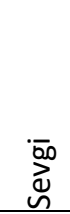 & $\begin{array}{l}\frac{5}{3} \\
\frac{3}{\varepsilon} \\
\frac{2}{0} \\
0\end{array}$ & 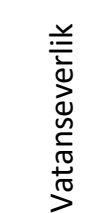 & 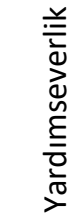 & $\begin{array}{l}\frac{\varepsilon}{\sigma} \\
\frac{\pi}{0} \\
\text { 은 }\end{array}$ \\
\hline $\begin{array}{l}\text { Merak } \\
\text { Ettiklerimiz }\end{array}$ & & - & - & - & - & - & - & - & - & - & 0 \\
\hline Afyon & & - & - & - & - & & & - & - & - & 0 \\
\hline
\end{tabular}




\begin{tabular}{|c|c|c|c|c|c|c|c|c|c|c|}
\hline Su Kirliliği & - & - & - & - & - & - & 2 & - & - & 2 \\
\hline $\begin{array}{l}\text { Kar Kristallerinin } \\
\text { Peşinde Bir } \\
\text { Yaşam }\end{array}$ & - & - & - & 0 & - & - & - & - & - & 0 \\
\hline Toplam & 0 & 0 & 0 & 0 & 0 & 0 & 2 & 0 & 0 & 0 \\
\hline
\end{tabular}

Tablo 6'ya göre "Doğa ve Evren” temasında yer alan "Merak Ettiklerimiz”, "Afyon”, "Kar Kristallerinin Peşinde Bir Yaşam" başlıklı metinlerde herhangi bir kök değer belirlenememiştir. "Su Kirliliği" başlıklı metinde ise sadece 2 tane sorumluluk kök değeri tespit edilmiştir.

Türkçe ders kitabında yer alan “Milli Kültürümüz” adlı temada yer alan metinler ve kök değerler Tablo 7'de gösterilmiştir.

Tablo 7. "Millî Kültürümüz" Temasında Yer Alan Metinlerin Kök Değerlerle ilişskisi

\begin{tabular}{|c|c|c|c|c|c|c|c|c|c|c|c|}
\hline METIN & $\frac{\frac{\pi}{0}}{\frac{\pi}{0}}$ & 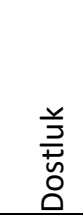 & 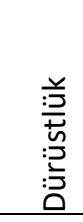 & 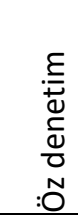 & $\begin{array}{l}\bar{\vdots} \\
\stackrel{0}{n} \\
\end{array}$ & 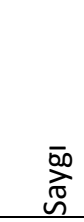 & 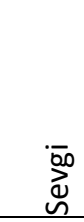 & $\begin{array}{l}\frac{\text { J }}{3} \\
\frac{\partial}{E} \\
\frac{3}{0} \\
0\end{array}$ & 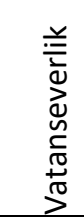 & 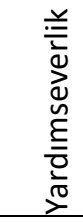 & $\frac{\frac{E}{\pi}}{\frac{\pi}{0}}$ \\
\hline Anadolu & - & - & - & - & - & - & - & - & 4 & - & 4 \\
\hline $\begin{array}{l}\text { Tarhananın } \\
\text { Öyküsü }\end{array}$ & - & - & - & - & - & & & - & - & - & 0 \\
\hline Ana Dili & - & - & - & - & - & - & - & 1 & 3 & - & 4 \\
\hline Kara Tren & - & - & - & - & 1 & - & - & - & 1 & - & 2 \\
\hline Toplam & 0 & 0 & 0 & 0 & 1 & 0 & 0 & 1 & 8 & 0 & 10 \\
\hline
\end{tabular}

Tablo 7’de "Millî Kültürümüz" temasında yer alan "Anadolu” başlıklı metinde sadece 4 vatanseverlik kök değeri bulunmaktadır. "Tarhananın Öyküsü” başlıklı metinde herhangi bir kök değer belirlenmemiştir. "Ana Dili” başlıklı metinde vatanseverlik 3, sorumluluk 1 olmak üzere toplam 4 kök değer tespit edilmiştir. "Kara Tren” başlıklı metinde sabır 1, vatanseverlik 1 olmak üzere toplam 2 kök değer tespit edilmiştir. "Milî̂ Kültürümüz" adlı temada yer alan metinlerde toplam vatanseverlik 8 , sabır ve sorumluluk kök değeri ise 1 kez görülmüştür. Adalet, dostluk, dürüstlük, öz denetim, saygı, sevgi, yardımseverlik kök değerleri ise belirlenememiştir.

Türkçe ders kitabında yer alan "Sağlık ve Spor" adlı temada yer alan metinler ve kök değerler Tablo 8'de gösterilmiştir. 


\begin{tabular}{|c|c|c|c|c|c|c|c|c|c|c|c|}
\hline METIN & $\frac{\frac{4}{0}}{\frac{\pi}{0}}$ & 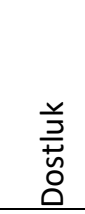 & 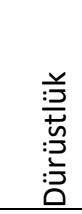 & 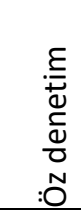 & $\begin{array}{l}\bar{\vdots} \\
\stackrel{\bar{N}}{n}\end{array}$ & 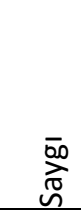 & 品 & $\begin{array}{l}\frac{2}{3} \\
\frac{3}{E} \\
\frac{\xi}{J} \\
0 \\
0\end{array}$ & 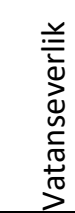 & 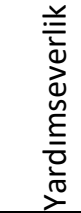 & $\begin{array}{l}\varepsilon \\
\frac{\varepsilon}{0} \\
\frac{0}{0} \\
\end{array}$ \\
\hline Bisiklet Zamanı & - & - & - & - & - & - & - & 2 & - & - & 2 \\
\hline $\begin{array}{l}\text { Yemek, İçmek ve } \\
\text { Sindirmek }\end{array}$ & - & - & - & 1 & - & & & 1 & - & - & 2 \\
\hline $\begin{array}{l}\text { Obezite } \\
\text { Hakkında } 10 \\
\text { Soru } 10 \text { Cevap }\end{array}$ & - & - & - & 2 & - & - & - & 1 & - & - & 3 \\
\hline $\begin{array}{l}\text { Vazgeçmeyenleri } \\
\text { n Hikâyesi }\end{array}$ & - & - & - & - & 1 & - & - & - & 2 & - & 3 \\
\hline Toplam & 0 & 0 & 0 & 3 & 1 & 0 & 0 & 4 & 2 & 0 & 10 \\
\hline
\end{tabular}

Tablo 8 incelendiğinde; "Sağlık ve Spor" temasında yer alan "Bisiklet Zamanı" başlıklı metinde sadece 2 sorumluluk kök tespit edildiği görülmektedir. "Yemek, İçmek ve Sindirmek" başlıklı metinde öz denetim 1, sorumluluk 1 olmak üzere toplam 2 kök değer tespit edilmiştir. "Obezite Hakkında 10 Soru 10 Cevap" başlıklı metinde öz denetim 2, sorumluluk 1 olmak üzere toplam 3 kök değer belirlenmiştir. "Vazgeçmeyenlerin Hikâyesi" başlıklı metinde vatanseverlik 2, sabır 1 olmak üzere toplam 3 kök değer tespit edilmiştir. "Sağlık ve Spor" adlı temada yer alan metinlerde toplam sorumluluk 4, öz denetim 3, vatanseverlik 2, sabır ise 1 kez görülmüştür. Adalet, dostluk, dürüstlük, saygı, sevgi, yardımseverlik kök değerleri ise belirlenememiştir.

Türkçe ders kitabında yer alan "Birey ve Toplum" adlı temada yer alan metinler ve kök değerler Tablo 9'da gösterilmiştir.

Tablo 9. "Birey ve Toplum" Temasında Yer Alan Metinlerin Kök Değerlerle ilişskisi

\begin{tabular}{|c|c|c|c|c|c|c|c|c|c|c|c|}
\hline METIN & $\frac{\frac{+}{0}}{\frac{\pi}{0}}$ & 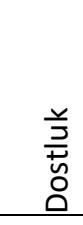 & 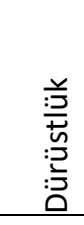 & 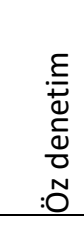 & $\frac{\grave{0}}{\stackrel{0}{n}}$ & 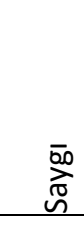 & 㐫 & 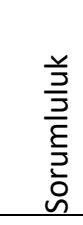 & $\begin{array}{l}\text { 兰 } \\
\frac{1}{d} \\
\text { d } \\
\frac{n}{\pi} \\
\frac{\pi}{\pi} \\
>\end{array}$ & 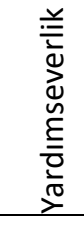 & $\frac{\frac{\varepsilon}{0}}{\frac{\pi}{0}}$ \\
\hline Evet Efendim & - & - & - & - & - & 1 & - & - & - & 1 & 2 \\
\hline $\begin{array}{l}\text { Sen de Bir İyilik } \\
\text { Yap }\end{array}$ & - & - & 4 & 1 & - & - & - & 1 & - & 1 & 7 \\
\hline Dostluğa Dair & - & 4 & - & - & - & 1 & - & - & - & - & 5 \\
\hline Hacettepe & - & - & - & - & - & - & - & - & - & - & 0 \\
\hline Toplam & 0 & 4 & 4 & 1 & 0 & 2 & 0 & 1 & 0 & 2 & 14 \\
\hline
\end{tabular}

Tablo 9'a göre "Birey ve Toplum" temasında yer alan "Evet Efendim” başlıklı metinde saygı 1, yardımseverlik 1 olmak üzere toplam 2 kök değer tespit edilmiştir. "Sen de Bir İyilik Yap" başlıklı metinde dürüstlük 4, öz denetim 1, sorumluluk 1, yardımseverlik 1 olmak üzere toplam 7 kök değer 


\section{Sınıf Türkçe Ders Kitabı’nda Yer Alan Temalardaki Metinlerin Kök Değerlerle İlişkisi}

bulunmuştur. "Dostluğa Dair" başlıklı metinde dostluk 4, saygı 1 olmak üzere toplam 5 kök değer tespit edilmiştir. "Hacettepe" başlıklı metinde ise herhangi bir kök değer belirlenememiştir. "Birey ve Toplum" adlı temada yer alan metinlerde toplam dostluk 4, dürüstlük 4, saygı 2, yardımseverlik 2, öz denetim ve sorumluluk ise 1 kez görülmüştür. Adalet, sabır, sevgi, vatanseverlik kök değerleri ise belirlenememiştir.

\section{Sonuç, Tartışma ve Öneriler}

Bu araştırmadan elde edilen verilere göre MEB 6. Sınıf Türkçe Ders Kitabı'nda yer alan toplam kök değerler; vatanseverlik (36), sevgi (21), yardımseverlik (18), sorumluluk (15), dostluk ve dürüstlük (8), sabır (6), öz denetim ve saygı (4), adalet (1) olarak belirlenmiştir. Ancak elde edilen veriler ışığımda 2018 Programda vurgulanan kök değerlerden adalet, saygı ve öz denetim kök değerlerine çok fazla değinilmediği söylenebilir.

Araştırmada elde edilen verilerin sonucuna göre adalet kök değerine yalnız dördüncü temada 1 kez rastlanmıştır. Diğer temalarda ise adalet kök değerine ait bulgu tespit edilememiştir. Dostluk kök değerine ait sekizinci temada 4, birinci ve dördüncü temada ise 2 bulgu görülmektedir. Diğer temalarda ise bu değere ilişkin veriye rastlanmamıştır. Dürüstlük kök değeri sekizinci temada 4, birinci temada 2, ikinci ve dördüncü temada ise 1 kez görülmektedir. Diğer temalarda tespit edilememiştir. Öz denetim kök değeri yedinci temada 3, sekizince temada ise 1 kez yer almaktadır. Diğer temalarda herhangi bir bulgu tespit edilememiştir. Sabır kök değeri birinci temada 2, üçüncü, dördüncü, altıncı ve yedinci temada ise 1 kez görülmektedir. Diğer temalarda bu kök değere ait herhangi bir bulgu yer almamaktadır. Saygı kök değeri üçüncü ve sekizinci temada 2 kez geçmektedir. Diğer temalarda belirlenememiştir. Sevgi kök değerine ilişkin dördüncü temada 8 , ikinci temada 6 , birinci temada 5 , üçüncü temada ise 2 bulguya rastlanmıştır. Diğer temalarda herhangi bir veri tespit edilememiştir. Sorumluluk kök değeri birinci ve yedinci temada 4, ikinci ve beşinci temada 1 , üçüncü, altıncı ve sekizinci temada 1 kez görülmekte, dördüncü temada ise herhangi bir bulgu yer almamaktadır. Vatanseverlik kök değerine ait ikinci temada 16, üçüncü temada 9, altıncı temada 8, yedinci temada 2 ve birinci temada 1 veri bulunmaktadır. Diğer temalarda herhangi bir bulguya rastlanmamıştır. Yardımseverlik kök değeri birinci temada 6, ikinci ve dördüncü temada 4, üçüncü ve sekizince temada ise 2 kez geçmektedir.

"Okuma Kültürü" temasında en çok yardımseverlik kök değeri yer almaktadır. "Heykeli Dikilen Eşek" başlıklı metin en fazla kök değere sahip olan metin olarak belirlenmiştir. "Milli Mücadele ve Atatürk" temasında en çok vatanseverlik kök değeri, "Bilim ve Teknoloji" temasında ise en çok vatanseverlik kök değeri yer almaktadır. Bu temada "120" başlıklı metin en fazla kök değere sahip olan metin olarak belirlenmiştir. Bilim ve teknoloji temasında "Aziz Sancar" başlıklı metin en fazla kök 
değere sahip olan metin olarak belirlenmiştir. "Erdemler" temasında en çok sevgi kök değeri yer almaktadır. Bu temada "Vermek Çoğalmaktır" başıkı ı metin en fazla kök değere sahip olan metin olarak belirlenmiştir. "Doğa ve Evren" temasında sadece "Su Kirliliği" başlıklı metinde 2 tane sorumluluk kök değeri tespit edilmiştir. "Merak Ettiklerimiz", "Afyon”, "Kar Kristallerinin Peşinde Bir Yaşam" başlıklı metinlerde herhangi bir kök değer belirlenememiştir. "Milli Kültürümüz" temasında en çok vatanseverlik kök değeri tespit edilmiştir. "Anadolu" ve "Ana Dili" başlıklı metinler en fazla kök değere sahip olan metin olarak belirlenmiştir. "Sağlık ve Spor" temasında en çok sorumluluk kök değeri tespit edilmiştir. "Obezite Hakkında 10 Soru 10 Cevap" ve "Vazgeçmeyenlerin Hikâyesi” başlıklı metinler en fazla kök değere sahip olan metin olarak belirlenmiştir. "Birey ve Toplum" temasında en çok dostluk ve dürüstlük kök değeri tespit edilmiştir. "Sen de Bir İyilik Yap" başıklı metin en fazla kök değere sahip olan metin olarak belirlenmiştir.

Bu verilere göre değerlerin dengesiz dağıldığı, kimi değerlere fazla yer verilirken kimi değerlere daha az rastlanıldığı sonucuna ulaşılmıştır.

Edebî eserlerin temel materyal olarak kullanıldığı Türkçe ders kitapları, çocuklara ve gençlere değer aktarımı için bir fırsat olarak değerlendirilebilir. Millî Eğitim Bakanlığı tarafından basılan 6. Sınıf Türkçe Ders Kitabı'nda yer alan metinlerin hangi kök değerleri ilettiğini tespit etmek ve bu değerlerin temalardaki metinlere göre dağılımını belirlemek amacıyla yapılan bu araştırmanın sonunda 6 . Sınıf Türkçe Ders Kitabı'nda yer alan metinlerin, değerlerin iletimini istenen düzeyde gerçekleştirmediği söylenebilir. Konu ile ilgili olarak yapılan Doğan ve Gülüşen (2011), Ekici Çelikpazu ve Aktaş (2011), Karagöz (2009), Somuncu (2008) tarafından yapılan araştırmalar bu araştırmanın verilerini destekler niteliktedir. Sosyal yaşama ilişkin değerler arasında yer alan saygı, yardımlaşma, aile birlikteliğini önemseme gibi değerlerin Türkçe ders kitaplarında yer alan metinler aracılığıyla iletildiği Kırmızı (2014), Şen (2008)'in yaptığı bir diğer araştırmada da benzer sonuçlara rastlanmaktadır.

Deniz ve Karagöl'ün (2018) yapmış olduğu benzer bir çalışmada da etkinliklerin metinlerden daha çok değer taşıdığı, değerlerin dengesiz dağıldığı, birkaç değere daha çok yer verilirken bazı değerlere daha az yer verildiği sonucuna ulaşıldığı görülmüştür. Dolayısı ile bu çalışmanın sonuçları da bizim çalışmamızı destekler niteliktedir.

Türkçe ders kitabındaki metinlerin, öğretim programında belirtilen tüm değer grupları açısından daha dengeli bir dağııım gösterecek şekilde seçilmesi gerekmektedir. Türkçe derslerinde gerek beceri gerekse değer kazandırma amacına hizmet eden en önemli araçların edebi eserler olması, Türkçe ders kitaplarına metin seçilirken daha dikkatli olunmasını zorunlu kılmaktadır.

Araştırma sonuçlarına dayalı olarak şu öneriler geliştirilebilir:

- $\quad$ Programda belirtilen kök değerlerin temalara dağııımı dengeli yapılabilir, 


\section{Sınıf Türkçe Ders Kitabı’nda Yer Alan Temalardaki Metinlerin Kök Değerlerle İlişkisi}

- $\quad$ Öğrencilerin değerleri yaparak yaşayarak öğrenmesi için uygulama olanaklar sağlanabilir,

- $\quad$ Türkçe ders kitaplarında yer alacak metinlerin seçimine özen gösterilmeli ve ders kitaplarına seçilen metinler Talim Terbiye Kurulu tarafından titizlikle incelenmelidir.

\section{Kaynaklar}

Akbaş, O. (2008). Değerler eğitimine genel bir bakış. Değerler Eğitimi Dergisi, 6(16), 9-27.

Aydın, M. Z (2010). Okulda değerler eğitimi. Ankara: Eğitime Bakış.

Bacalı, H. (2011). Değer Değer Midir?. Eğitime Bakış, 7(19), 18-21.

Berkowitz Marvin W. (2011) What works in values education. International Journal of Educational Research, 50(3), 153-158

Demiral, Ö. ve Kaya Z. (2012). Eğitim bilimine giriș. Ankara: Pegem Akademi.

Deniz, K. ve Karagöl, E. (2018). Değerler Eğitimi Açısından Ortaokul Türkçe Ders Kitapları. Karaelmas Journal of Educational Sciences, 6(2), 244-255.

Doğan, B. ve A. Gülüşen (2011). Türkçe ders kitaplarındaki (6-8) metinlerin değerler bakımından incelenmesi. Sosyal Bilimler Dergisi, 1(2), 75-102.

Ekici Çelikpazu, E. ve Aktaş E. (2011). MEB 6, 7 ve 8. sınıf Türkçe ders kitaplarında yer alan metinlerin değer iletimi açısından incelenmesi. Turkish Studies International Periodical For the Languages, Literature and History of Turkish or Turkic, 6(2), 413-424.

Fidan, N. (1986). Okulda öğrenme ve öğretme. Ankara: Pegem Akademi.

Güçlü, M. (2015). Türkiye'de değerler eğitimi konusunda yapılan araştırmalar. Eğitimde Gelecek Arayışları: Dünden Bugüne Türkiye'de Beceri, Ahlak ve Değerler Eğitimi Uluslararası Sempozyumu. Bartın: Atatürk Araştırma Merkezi.

Güneş, F. (2015). Değerler eğitiminde yaklaşım ve modeller. Eğitimde Gelecek Arayışları: Dünden Bugüne Türkiye'de Beceri, Ahlak ve Değerler Eğitimi Uluslararası Sempozyumu. Bartın: Atatürk Araştırma Merkezi.

Karagöz, B. (2009). Yapılandırmacı yaklaşıma göre ilköğretim 6 ve 7. sınıf Türkçe ders kitaplarındaki değerlerin incelenmesi. Yüksek Lisans Tezi, Muğla Sıtkı Koçman Üniversitesi Sosyal Bilimler Enstitüsü, Muğla.

Kırmızı Susar, F. (2014). 4. sınıf Türkçe ders kitabı metinlerinde yer alan değerler. Değerler Eğitimi Dergisi, 12(27), 217-259.

McCullough, M.E., \& Snyder, C.R. (2000). Classical sources of human strength: Revisiting an old home and building a new one. Journal of Social and Clinical Psychology, 19, 1- 10.

Merriam, S. B. (2013). Qualitative research a guide to desing and implementation. Selahattin Turan (Çev. Ed.). 3. Basımdan Çeviri. Ankara: Nobel Yayınları.

MEB, (2006). Ilköğretim Türkçe Dersi (6, 7, 8. Sınıflar) Öğretim Programı. Ankara: Millî Eğitim Bakanlığı Yayınları.

MEB (2018). Ortaokul ve imam hatip ortaokulu 6. sınıf Türkçe ders kitabı. Ankara: Talim ve Terbiye Kurulu Başkanlığı.

MEB (2018). Illköğretim Türkçe Dersi Öğretim Programı. Ankara: Millî Eğitim Bakanlığı Yayınları.

Öncül, R. (2000). Eğitim ve eğitim bilimleri sözlüğü. İstanbul: Millî Eğitim Basımevi.

Peterson, C. ve Seligman, M. E. P. (2004). Character strengths and virtues a handbook and classification. New York: Oxford University Press. 
Somuncu, S. (2008). Ilköğretim 7. sınıf Türkçe ders kitabındaki edebî metinlerin temel evrensel değerleri içermesi bakımından incelenmesi. Yüksek Lisans Tezi, Kocatepe Üniversitesi Sosyal Bilimler Enstitüsü, Afyonkarahisar.

Sönmez, V. ve Alacapınar, F. G. (2013). Örneklendirilmiş bilimsel araştırma yöntemleri. Ankara: Anı Yayıncılık.

Şen, Ü. (2008). 6.sınıf Türkçe ders kitaplarındaki metinlerin ilettiği değerler açısından incelenmesi. KKTC: Uluslararası Türkçe Eğitimi ve Öğretimi Sempozyumu.

TDK (2005). Büyük Türkçe Sözlük. Ankara: Türk Dil Kurumu Yayınları.

Temizyürek, F. ve Balcı, A. (2013). Cumhuriyet dönemi ilköğretim okulları Türkçe programları, Ankara: Nobel Yayınları.

Yıldırım, A. ve Şimşek H. (2011). Sosyal bilimlerde nitel araştırma yöntemleri. Ankara: Seçkin Yayıncılık.

\section{Extended Abstract}

Introduction

It has been noted that the teaching of the values which are defined as "the principles or standards of behavior" and form the building blocks of a society are referred to as "values education" in the studies conducted in Turkey and as "character education" in international studies. Studies in the field have been gaining importance in recent times.

The most important determinant that separates humans from other living beings and artificial intelligence is the values that they hold. The character which the individual possesses is in a sense the amalgamation of the values they hold. McCullough and Snyder (2000) explain the concept of value in relation to psychology and define it as the psychological process, encompassing individuals' thoughts and behaviors which are beneficial to themselves and the society as a whole. They point out that these virtues come together and form a higher concept known as "character". Peterson and Seligman (2004) on the other hand explain positive traits through the concept of values and claim that such values come together and form "virtues". Therefore, the most important part of character development and forming of virtues is the values which the individual possesses.

School life forms a large part of the process in which values are formed in individuals. The individual initially begins to internalize values present in their family environment such as respect, love and assistance. Afterwards, through texts presented in their courses, most importantly among them, the Turkish course and social interactions with their peers, they learn various values. Thus, they prepare themselves for the future and life (Güneş, 2015)

In the reformed Turkish Education Program (2018), it is emphasized that attaining values is a task of education programs. In this program, values are not seen as a separate program, learning field, unit, subject and the like. The ultimate goal of education is to teach the values that are present in every education program and in each section of the aforementioned program. "Core values" in these education programs are listed as; justice, honesty, self-reflection, patience, respect, love, responsibility, patriotism and charity.

The aim of this study is to determine the relationship between the core values present in the Turkish Course Education Program (2018) and the texts of the $6^{\text {th }}$ grade Turkish course books and to determine the units in which these values are represented in text. The values which guide the behavior of the individual to conform to the society are mainly expressed through Turkish course book texts. This is due to the fact that these texts are the most concrete elements through which such a goal can be attained.

\section{Method}

The research is qualitative by design. Qualitative research is commonly used in in all disciplinary and practical areas of education. This research type collects data through observation, interview or document review (Merriam, 2013).

\section{Result and Discussion}

The data analysis showed that the core values identified in the MEB $6^{\text {th }}$ grade Turkish course books and their frequency of occurrence are patriotism (36), love (21), charity (18), responsibility (15), friendship and honesty (8), patience (6), self-reflection and respect (4), and justice (1). However, it can be said that in the data that were collected, the core values of justice, respect and self-reflection were not paid due attention.

It was concluded that the distribution of these core values had been done in an arbitrary way, giving extra attention to some and lacking others.

The following suggestions may be made, based on the conclusions of this study:

- Distribution of core values defined in the program may be balanced further 


\section{Sınıf Türkçe Ders Kitabı’nda Yer Alan Temalardaki Metinlerin Kök Değerlerle Ilişkisi}

- Efforts may be directed to allow students to learn these core values through first-hand experience

- Texts which are to be placed in Turkish course books should be selected carefully and chosen texts should be thoroughly examined by the Board of Education. 